\title{
Halophyte Planting Improves Saline-Alkali Soil and Brings Changes in Physical and Chemical Properties and Soil Microbial Communities
}

\author{
Xueqin Wang ${ }^{1}$, Fengju Zhang' ${ }^{2}$ Bo Zhang ${ }^{3}$, Xing Xu ${ }^{1 *}$ \\ ${ }^{1}$ Agricultural College, Ningxia University, Ningxia Hui Autonomous Region, 750021, China \\ ${ }^{2}$ Northwest Land Degradation and Ecological Restoration of State Key Laboratory Cultivation Base, \\ College of Ecological Environment, Ningxia University, Ningxia Hui Autonomous Region, 750021, China \\ ${ }^{3}$ National Wolfberry Engineering Research Center, Ningxia Academy of Agriculture and Forestry Sciences, \\ Ningxia Hui Autonomous Region, 750021, China
}

Received: 24 September 2020

Accepted: 8 March 2021

\begin{abstract}
In this study, 5 kinds of halophytes were used to improve the saline-alkali soil, including Panicum virgatum L. (SG), Achnatherum splendens (Trin.) Nevski (AS), Leymus chinensis (Trin.) Tzvel. (CG), Sphaerophysa salsula (Pall.) DC. (SS), and Sophora alopecuroides L. (SA). The soil bacteria 16S RNA amplicon sequencing was performed by an Illumina Miseq platform. Planting of halophytes increases the content of organic matter, total nitrogen, total phosphorus, available phosphorus, and alkalihydrolyzed nitrogen in the soil. Sphaerophysa salsula (Pall.) DC. (Sphaerophysa salsula) has the most significant improvement effect on saline-alkali land. In soil, Proteobacteria play a crucial role in the degradation of soil organic matter, which may be an important factor in improving saline-alkali soil. Besides, root exudates of halophytes might promote Proteobacteria growth, especially in Sphaerophysa salsula (Pall.) DC. and Sophora alopecuroides L. (Sophora alopecuroides). Halophyte planting has a significant impact on the restoration of saline-alkali soil.
\end{abstract}

Keywords: halophytes, saline-alkali soil, improvement, physical and chemical properties, soil bacterial community

\section{Highlights}

- Halophyte planting has a significant impact on the restoration of saline-alkali soil, and provide reference methods for the biological improvement of saline- alkali soils - halophyte planting has affected soil microbial structure, and the effect of Sphaerophysa salsula (Pall.) DC. is prominent.

- Proteobacteria plays a crucial role in the degradation of soil organic matter, which may be an important factor in improving saline-alkali soil.

- Halophytes interact with soil microorganisms to repair soil salinity. 


\section{Introduction}

Salt and Alkali Stresses are one of the major abiotic stresses on plants and have seriously affected agricultural productivity in most parts of the world $[1,2]$. Especially in arid and semi-arid regions, soil salinization is a major threat to agriculture, where water scarcity and inadequate irrigation management severely reduce crop yield [3]. At present, the development of saline-alkali agriculture using salt-tolerant economic plants is a feasible way to utilize saline-alkali land [46]. In Northwest China, halophytes are important cash crops, and farmers have good forages planting practices. Therefore, it is of great significance to explore halophyte planting for the biological improvement of salinealkali land. Some grasses, especially wild forages, often show durable survivability and have a strong resistance to stress. For instance, several legumes, including Medicago sativa (alfalfa) and M. truncatula, have cultivars that have adapted to saline soils [7]. There are precedents for the use of salt-tolerant plants to improve saline-alkali land, and the critical role of 'plant-microbe interaction' is pointed out [8-11]. When plants suffer from salt stress, a series of responses occur, and different plants respond differently [12]. While responding to stress, the plant root system also produces various secretions. Previous studies reported that a small change in the composition and quantity of root exudates causes major changes in the population of microorganisms in the root zone $[13,14]$. Furthermore, the organisms in the soil can as well influence the plants by releasing regulatory substances [15]. In this way, a virtual circle is gradually established, and the salinealkali land is greatly improved in the process. Wang et al. reviewed the biological improvement of saline-alkali soil reference system and noted that suitable varieties, suitable cultivation measures, and comprehensive evaluation system were the three critical aspects of evaluating improved methods [1]. As a supplement, this study will reveal the effects of halophyte planting on bacterial community structure in the saline-alkali land.

In this study, we evaluated the improvement effects of several pastures on saline-alkali soil. In addition, we also revealed the changes in soil microbial communities in rhizosphere soil and bulk soil after planting of different forages by high-throughput sequencing. This study will provide reference methods for the biological improvement of saline-alkali soils. In addition, it also provides a theoretical basis for the establishment of other biological improvement methods for saline-alkali soils.

\section{Materials and Methods}

\section{Experimental Location}

The present study was carried out on the saline alkali land in Ningxia Shizuishan City Pingluo County Qianjin
Farm, Ningxia University Saline Land Improvement Test Station (E-106 $28^{\prime}$; N-39 $\left.05^{\prime}\right)$. The average annual precipitation at this location is $172.5 \mathrm{~mm}$, which is mainly concentrated in July, August, and September. However, the annual mean surface evaporation is greater than the annual mean precipitation, which is approximately $1755 \mathrm{~mm}$. Besides, the average sunshine hours are 2800-3200 $\mathrm{h}$. The average annual temperature is $8.5^{\circ} \mathrm{C}$ with diurnal difference of $8-15^{\circ} \mathrm{C}$. Frost-free period last 155 days per year and the annual average relative humidity is $56 \%$. The $\mathrm{pH}$ value was measured using an INESA pH meter (Shanghai REX Instrument Factory, Shanghai, China). Total dissolved solids (TDS) were measured in situ using a portable SG3 conductivity meter (Mettler-Toledo Co., Shanghai, China). Total alkalinity (TA) was measured using a Metrohm autotitrator (Metrohm Co., Herisau, Switzerland). The data were calculated according to Zhang's report [16]. The values of $\mathrm{pH}$, TDS and TA was 9.1, 3.02, and 20.6\%, respectively.

\section{Experimental Design and Samples Collection}

In the present study, 5 common halophyte species in Northwest China were selected to improve the saline-alkali soil, including Panicum virgatum L. (SG), Achnatherum splendens (Trin.) Nevski (AS), Leymus chinensis (Trin.) Tzvel. (CG), Sphaerophysa salsula (Pall.) DC. (SS), and Sophora alopecuroides L. (SA). The seeds (and seedlings) were obtained from Forage Experiment Station of Inner Mongolia Agricultural University. The bare ground with no pasture was set as control (CK). For the test areas, a total of three areas are divided, each area includes six blocks. The block is 6 meters long, 5 meters wide, and an area of $30 \mathrm{~m}^{2}$. The area spacing is $1.5 \mathrm{~m}$; block spacing is $1 \mathrm{~m}$. A 5-meter wide protection line was set up to isolate the test area.

The experiment was performed with a completely randomized block design with three replications. Three soil samples $(5$-cm diameter $\times 30 \mathrm{~cm}$ depth) were collected randomly in each plot before planting. The halophytes seeds (AS, SS and SA) and seedlings (SG and $C G$ ) were sown (20 cm row spacing) on the $17^{\text {th }}$ and $18^{\text {th }}$ of April in 2017, respectively. The experiment ended in July 2018. All seedlings were managed under the general field management methods, and no fertilization was done for the whole growing period.

Bulk soil and rhizosphere soil samples were collected from the experimental field. On July 25, 2018. Three replicates were randomly selected from each plot to collect rhizosphere soil, and then mixed as one sample. For bulk soil samples, a five-point sampling method was used to collect the soil samples. All the collected samples were transported in a dry ice sampling box and stored at $-80^{\circ} \mathrm{C}$. Each sample was divided into two parts, one of which was used to determine the physical and chemical properties of soil according to Lu's methods [17], and the other was used 
to analyze 16S RNA of soil microorganisms. Briefly, the soil organic matter $(\mathrm{OM})$ content was determined using the potassium dichromate volumetric method; Total nitrogen (TN) was determined by Kjeldahl method; Total phosphorus (TP) was determined using sulfuric acid-perchloric acid digestion method; Alkaline hydrolyzed nitrogen ( $\mathrm{HyN})$ was determined by alkalihydrolyzed reduction diffusing method; Available potassium (AK) was determined using the sodium bicarbonate extraction-molybdenum-antimony antispectrophotometric method; Available phosphorus (AP) was determined by Olsen method; Soil pH was measured with glass electrode in a 1:2.5 soil/water suspension. Exchangeable sodium percentage (ESP) were calculated directly, based on the concentrations of exchangeable cations; Total salt content was detected by heating drying method.

Finally, a total of 11 groups (33 soil samples) were used for sequencing, including the control group (CK); bulk soil groups of Panicum virgatum L. (marked as SG), Achnatherum splendens (Trin.) Nevski (marked as AS), Leymus chinensis (Trin.) Tzvel. (marked as CG), Sphaerophysa salsula (Pall.) DC. (marked as SS), and Sophora alopecuroides L. (marked as SA); and rhizosphere soil groups of Panicum virgatum $L$. (marked as SG-r), Achnatherum splendens (Trin.) Nevski (marked as AS-r), Leymus chinensis (Trin.) Tzvel. (marked as CG-r), Sphaerophysa salsula (Pall.) DC. (marked as SS-r), and Sophora alopecuroides $L$. (marked as SA-r). All the groups and their abbreviations were listed in Table 1

\section{DNA Extraction and Sequencing}

DNA was extracted from $1 \mathrm{~g}$ soil of each sample using a PowerSoil DNA Isolation Kit (MOBIO, Carlsbad, CA, USA). Then the DNA concentration was quantified by a Qubit 2.0 Fluorometer (Invitrogen, Carlsbad, CA, USA). The V3 and V4 region of the 16S rRNA gene was amplificated with $341 \mathrm{~F}$ (5'-3': CCTAYGGGRBGCASCAG)/806R (5'-3': GGACTACHVGGGTWTCTAAT) primers. A $20 \mu \mathrm{L}$ PCR reaction system was used containing $2 \mu \mathrm{L}$ template DNA, $0.5 \mu \mathrm{L}$ of each forward- and reverse-primer, $10 \mu \mathrm{L}$ PCR mix (2×, BioTeke, Wuxi, Jiang Su, China), and $7 \mu \mathrm{L}$ dd $\mathrm{H}_{2} \mathrm{O}$. The PCR amplification was performed as follows: one cycle of $95^{\circ} \mathrm{C}$ for $15 \mathrm{~min}$, followed by 35 cycles of $94^{\circ} \mathrm{C}$ for $30 \mathrm{sec}, 55^{\circ} \mathrm{C}$ for $30 \mathrm{sec}$, and $72^{\circ} \mathrm{C}$ for $45 \mathrm{sec}$, and followed by a final extension at $72^{\circ} \mathrm{C}$ for 5 min. PCR products from one sample were pooled and then gel purified ( $2 \%$ agarose gel) using a GeneJETTM Gel Extraction Kit (Thermo Fisher, Waltham, MA, USA). DNA quantification was performed using QuantiFluo (Promega, Lyon, France). DNA library construction was performed using the MetaVx ${ }^{\mathrm{TM}}$ Library Preparation kit (GENEWIZ, South Plainfield, Nan Jing, USA), and 16S rRNA gene sequencing was performed on the Illumina Miseq platform (Illumina, San Diego, USA; Pair-end 300 bp).

\section{Bioinformatic Analysis}

After the double end sequencing of DNA, the original data were saved in FASTQ format. The QIIME (V1.9.1, http:/qiime.org/) software was then used to identify and eliminate the query sequence and USEARCH (V8.1.1861, https://www.drive5.com/ usearch/download.html) was employed to check and remove the chimera sequences to obtain high-quality sequences. The number of high-quality sequences of each sample and the length distribution of the highquality sequences in the whole sample were calculated using the R software (V3.2.0, https://www.r-project. org/). High-quality sequences with $\geq 97 \%$ nucleotide similarity were clustered into operational taxonomic units (OTUs) with QIIME as described previously [18]. Briefly, reads were demultiplexed and primers and barcodes were trimmed using QIIME's default settings. Following trimming, paired end sequence reads were merged with default QIIME settings and clustered into OTUs against the Silva 132 16S rRNA database (http:// www.arb-silva.de/) which has taxonomic categories predicted to the species level. Shared OTU abundances were visualized using a Venn diagram. Rarefaction curves and rank-abundance curves were calculated in QIIME. Then, sequences were rarefied prior to the calculation of alpha diversity indexes using QIIME, including Chaol, Shannon, ace, and Simpson. Beta diversity (diversity between the samples) was measured using weighted UniFrac analysis (http://bmf.colorado. edu/unifrac/index.psp). The stacked bar graphics were prepared to represent OTU relative abundance metrics in $\mathrm{R}$, using the gplots package. Heat maps were graphed in TBtools (V0.66839, https://github. com/CJ-Chen/TBtools) base on the dominant bacteria. Linear discriminant analysis (LDA) coupled with effect size (LEfSe) was performed using the LEfSe program (http://huttenhower.sph.harvard.edu/galaxy/root?tool id=lefse_upload).

\section{Statistical Analysis}

Statistical analysis was performed following previous studies $[19,20]$. SPSS 22.0 software was used for statistical data analysis. Data were expressed as the mean \pm SD and analyzed by one-way ANOVA followed by multiple comparisons with Duncan test. A value of $p<0.05$ was considered significant, and $p<0.01$ was considered highly significant.

\section{Results}

\section{Effects of Different Grasses on Physical and Chemical Properties of Soil}

Halophyte planting dramatically altered soil physicochemical properties. After planting, the values of TN, OM, AP, and HyN in the soil increased 


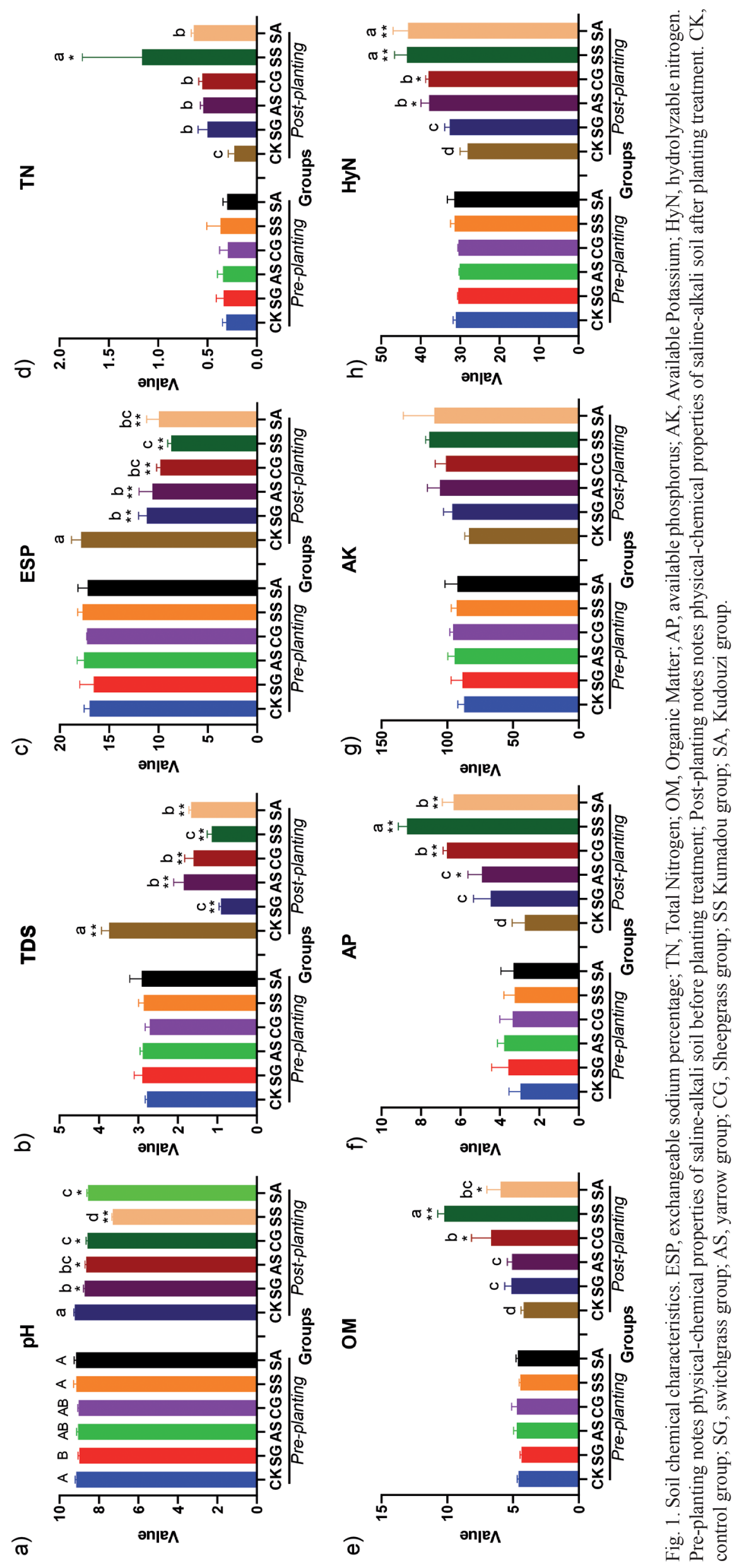


significantly; the $\mathrm{pH}$, total salt content, and ESP were all significantly decreased. The land planted with Sphaerophysa salsula (Pall.) DC. (SS) had the highest values of TN, OM, AP, and HyN, which were significantly higher than the land before planting. Correspondingly, planting Sphaerophysa salsula (Pall.) $D C$. had the most significant effects on $\mathrm{pH}$, total salt content, and ESP of the saline soils (Fig. 1). In addition, we found that halophyte planting treatment had no effects on AK content. The soil water content and porosity test results showed that forage grass planting significantly increased the AWC, total porosity, and capillary porosity (Fig. 2). Similarly, Sphaerophysa salsula (Pall.) DC. showed outstanding effects on saline-alkali land improvement, which had a higher value of $\mathrm{AWC}$, total porosity, and capillary porosity than that of other halophyte planting treatments. Panicum virgatum L. (SG) and Achnatherum splendens (Trin.) Nevski (AS) planting decreased the value of non-capillary porosity, but Leymus chinensis (Trin.)
Tzvel. (CG) and Sophora alopecuroides L. (SA) increased it.

\section{Effects of Different Grasses on Enzyme Activities of Soil}

As expected, the effect of forage application on enzyme activity in saline-alkali soils was extremely significant. Halophyte planting treatment led to a significant increase in all the tested enzyme activities. After Sphaerophysa salsula (Pall.) DC. treatment, the activities of ALP, NR, and Urease increased the most. Sophora alopecuroides L. treatment induced the activities of CAT and Invertase, which was significantly higher than the other treatments (Fig. 3). Among the halophytes, Achnatherum splendens (Trin.) Nevski showed a lower value of ALP, CAT, NR, and Urease activities. Panicum virgatum $L$. treatment showed a lower value of Invertase. a)

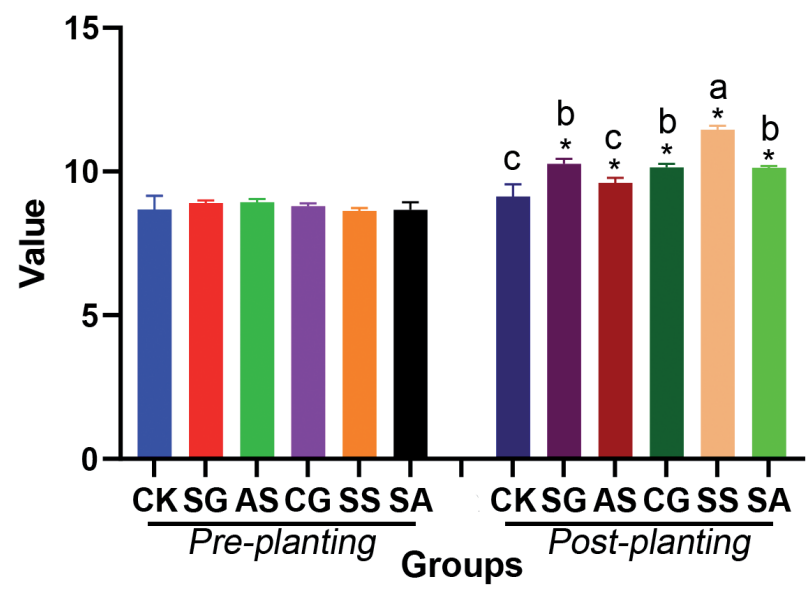

c)

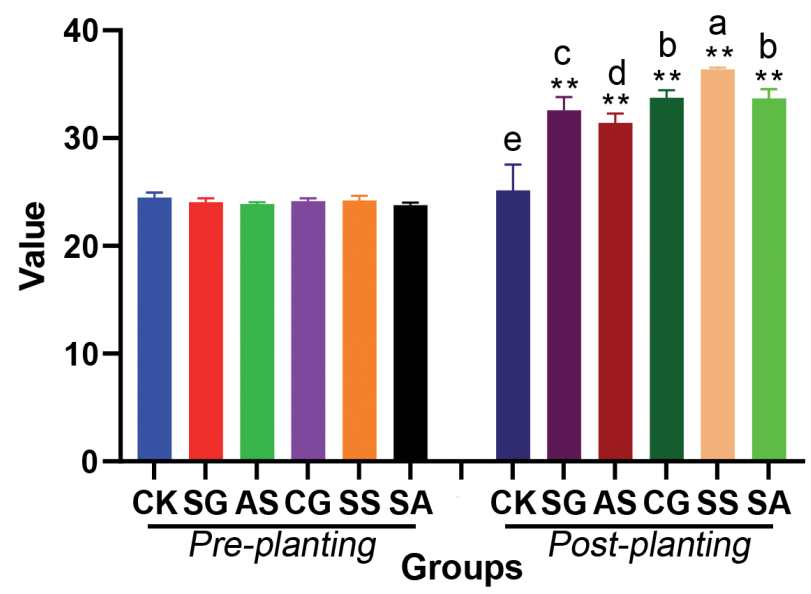

b)

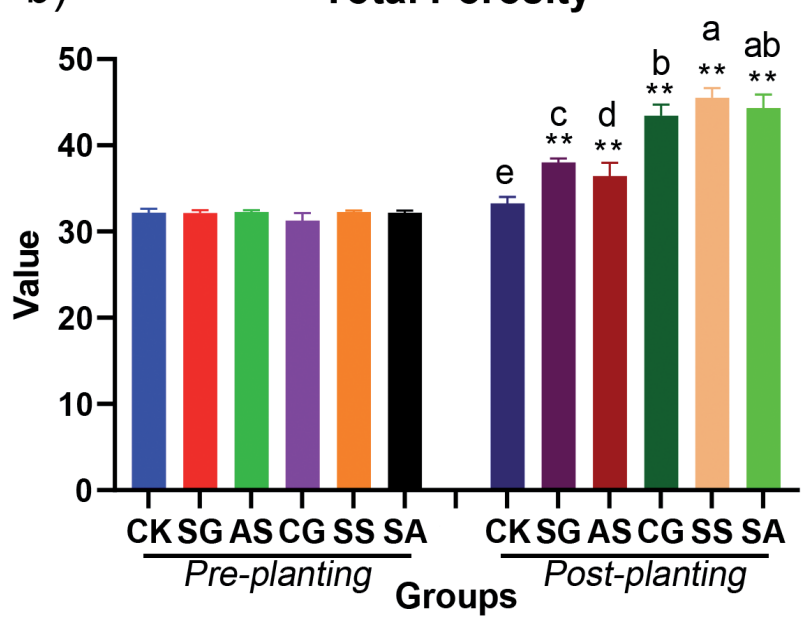

d)

non-Capillary Porosity

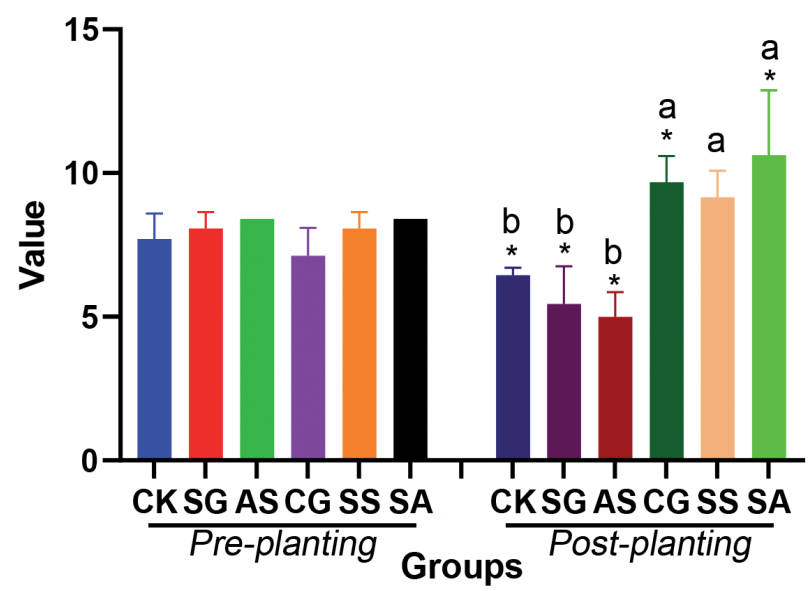

Fig. 2. Soil physical characteristics. AWC, absolute water content; Pre-planting notes physical-chemical properties of saline-alkali soil before planting treatment; Post-planting notes notes physical-chemical properties of saline-alkali soil after planting treatment. CK, control group; SG, switchgrass group; AS, yarrow group; CG, Sheepgrass group; SS Kumadou group; SA, Kudouzi group. 


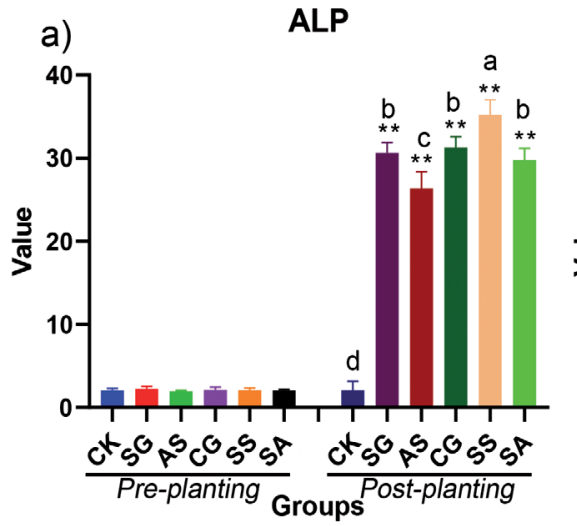

d)

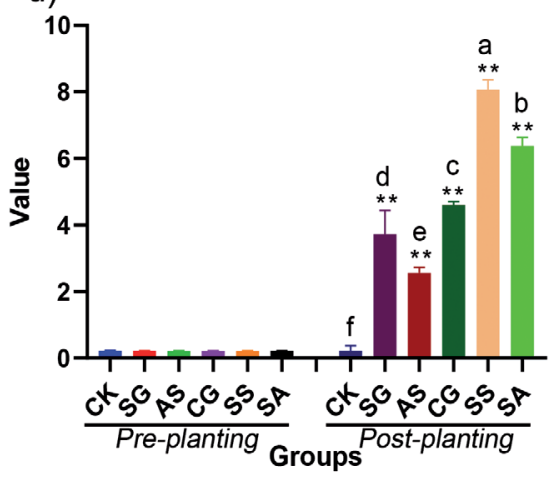

CAT

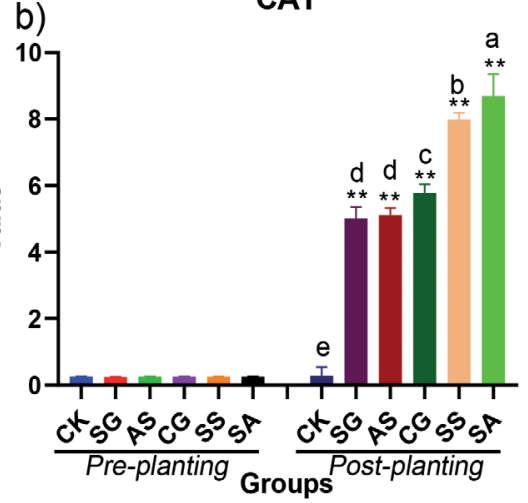

e) c)

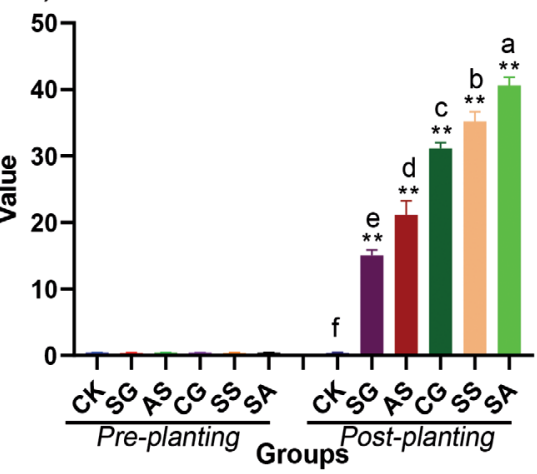

Urease
Invertase

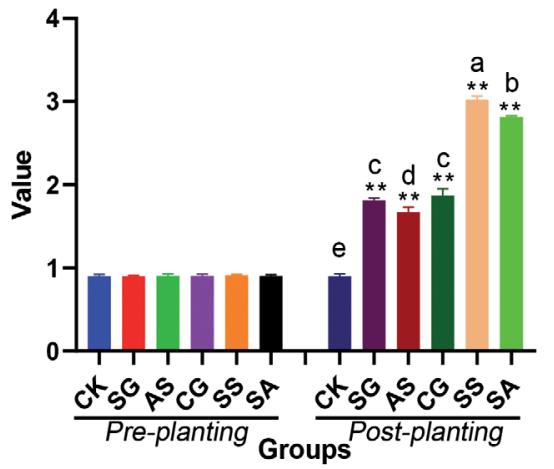

Fig. 3. Soil enzyme activities. ALP, alkaline phosphatase; CAT, catalase; NR, nitrate reductase; Pre-planting notes physical-chemical properties of saline-alkali soil before planting treatment; Post-planting notes physical-chemical properties of saline-alkali soil after planting treatment. CK, control group; SG, switchgrass group; AS, yarrow group; CG, Sheepgrass group; SS Kumadou group; SA, Kudouzi group.

\section{Sequence Data Summary}

Based on sequencing analysis of the V3 and $\mathrm{V} 4$ regions of the 16s rRNA gene, a mass of paired

Table 1. Groups and their abbreviations.

\begin{tabular}{|c|c|}
\hline Group name & $\begin{array}{c}\text { Abbre- } \\
\text { viations }\end{array}$ \\
\hline Control group & CK \\
\hline Bulk soil of Panicum virgatum L. & SG \\
\hline Bulk soil of Achnatherum splendens (Trin.) Nevski & $A S$ \\
\hline Bulk soil of Leymus chinensis (Trin.) Tzvel & GG \\
\hline Bulk soil of Sphaerophysa salsula (Pall.) DC & SS \\
\hline Bulk soil of Sophora alopecuroides L. & SA \\
\hline Rhizosphere soil groups of Panicum virgatum L. & SG-r \\
\hline $\begin{array}{c}\text { Rhizosphere soil of Achnatherum splendens (Trin.) } \\
\text { Nevski }\end{array}$ & AS-r \\
\hline Rhizosphere soil of Leymus chinensis (Trin.) Tzvel. & GG-r \\
\hline Rhizosphere soil of Sphaerophysa salsula (Pall.) & SS-r \\
\hline DC. & SA-r \\
\hline
\end{tabular}

sequences with barcode and primer sequences were obtained. We identified 1,730,483 pair-end reads from the 33 soil samples, with an average length of $454 \mathrm{bp}$. The average Q20, Q30, and GC contents were $91.31 \%$,

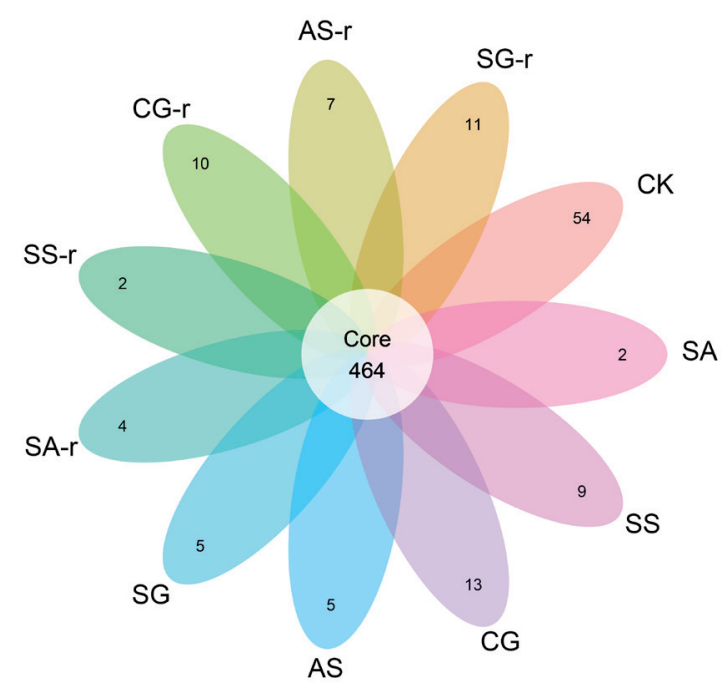

Fig. 4. Operational Taxonomic Units (OTU) based petal maps. CK, control group; SG, switchgrass group; AS, yarrow group; CG, Sheepgrass group; SS Kumadou group; SA, Kudouzi group; -r means rhizosphere soil samples. 
$86.95 \%$, and $56.19 \%$, respectively, and the clean reads of Q20 occupied over 95\% of the total, suggesting high-quality sequencing (Table S1). In total, 3,460,966 sequenced reads were clustered into 2,318 OTUs, of which there were 464 core OTUs were identified in all the groups (Fig. 4).

\section{Soil Bacteria Richness and Diversity}

All the optimized reads were classified into OTUs under different taxonomic levels (Table 2). The rarefaction curves based on the OTUs of the bacterial community in soil reached saturation plateau, indicating that the sequencing depth was sufficient to represent

Table 2. Numbers of OTUs in different samples.

\begin{tabular}{|c|c|c|c|c|c|c|c|}
\hline Sample & Phylum & Class & Order & Family & Genus & Species & Unclassified \\
\hline CK_1 & 505 & 502 & 420 & 396 & 296 & 197 & 2 \\
\hline CK_2 & 451 & 447 & 397 & 363 & 275 & 185 & 1 \\
\hline CK_3 & 578 & 572 & 485 & 457 & 349 & 229 & 1 \\
\hline SG_r_1 & 1460 & 1453 & 1254 & 1135 & 919 & 543 & 0 \\
\hline SG_r_2 & 1367 & 1360 & 1178 & 1072 & 868 & 510 & 0 \\
\hline SG_r_3 & 1428 & 1422 & 1235 & 1113 & 904 & 539 & 2 \\
\hline AS_r_1 & 1367 & 1359 & 1166 & 1051 & 846 & 508 & 0 \\
\hline AS_r_2 & 1330 & 1323 & 1151 & 1040 & 837 & 505 & 0 \\
\hline AS_r_3 & 1436 & 1430 & 1235 & 1115 & 901 & 533 & 1 \\
\hline CG_r_1 & 1228 & 1224 & 1059 & 959 & 765 & 444 & 0 \\
\hline CG_r_2 & 1373 & 1366 & 1182 & 1058 & 861 & 507 & 0 \\
\hline CG_r_3 & 1116 & 1112 & 975 & 881 & 703 & 421 & 2 \\
\hline SS_r_1 & 1220 & 1219 & 1080 & 979 & 791 & 450 & 2 \\
\hline SS_r_2 & 1339 & 1334 & 1170 & 1052 & 865 & 502 & 2 \\
\hline SS_r_3 & 1375 & 1370 & 1194 & 1070 & 859 & 508 & 2 \\
\hline SA_r_1 & 1228 & 1294 & 1132 & 1021 & 824 & 480 & 2 \\
\hline SA_r_2 & 1337 & 1333 & 1178 & 1061 & 861 & 495 & 2 \\
\hline SA_r_3 & 1386 & 1381 & 1201 & 1086 & 881 & 519 & 1 \\
\hline SG_1 & 1491 & 1486 & 1285 & 1145 & 929 & 560 & 1 \\
\hline $\mathrm{SG}_{-2}$ & 1346 & 1339 & 1168 & 1053 & 842 & 500 & 1 \\
\hline SG_3 & 1376 & 1369 & 1179 & 1053 & 851 & 497 & 0 \\
\hline AS_1 & 1337 & 1330 & 1150 & 1035 & 828 & 480 & 1 \\
\hline AS_2 & 1258 & 1255 & 1096 & 988 & 795 & 472 & 0 \\
\hline AS_3 & 1423 & 1418 & 1226 & 1098 & 877 & 527 & 0 \\
\hline CG_1 & 1279 & 1275 & 1111 & 1009 & 808 & 476 & 0 \\
\hline CG_2 & 1420 & 1415 & 1226 & 1102 & 890 & 533 & 0 \\
\hline CG_3 & 1085 & 1080 & 936 & 851 & 675 & 403 & 0 \\
\hline SS_1 & 1505 & 1497 & 1306 & 1181 & 939 & 565 & 0 \\
\hline SS_2 & 1412 & 1407 & 1225 & 1098 & 893 & 516 & 0 \\
\hline SS_3 & 1374 & 1370 & 1189 & 1072 & 875 & 520 & 0 \\
\hline SA_1 & 1358 & 1352 & 1176 & 1052 & 854 & 486 & 0 \\
\hline SA_2 & 1404 & 1398 & 1208 & 1091 & 873 & 521 & 0 \\
\hline SA_3 & 1448 & 1443 & 1244 & 1121 & 907 & 534 & 0 \\
\hline
\end{tabular}


a)

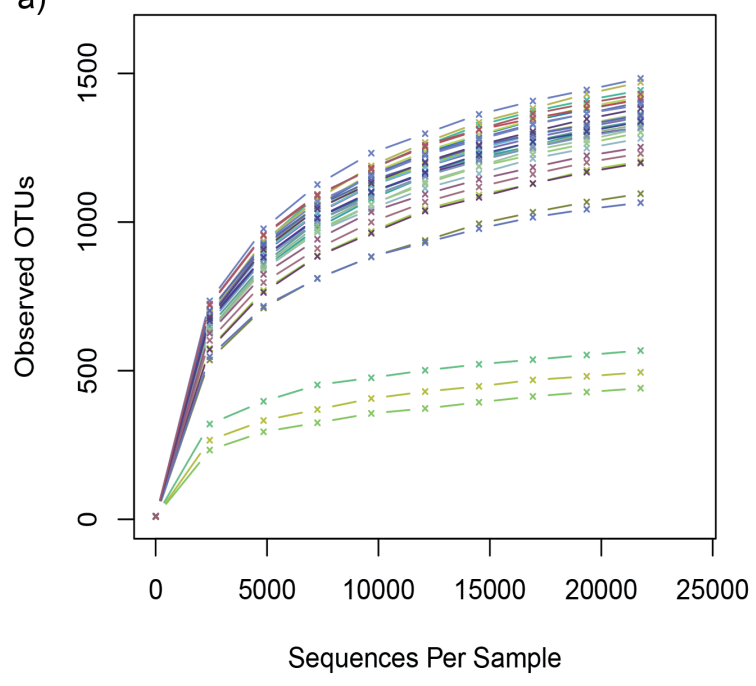

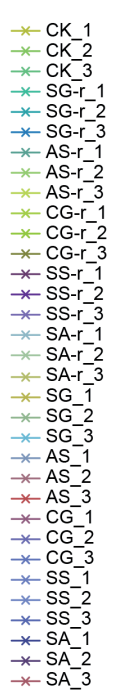

b)

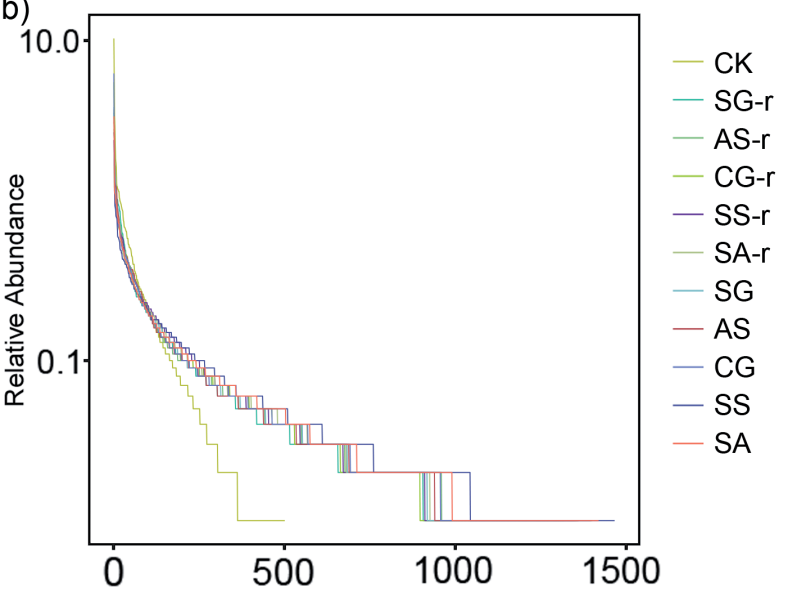

OTU Rank

Fig. 5. Rarefaction curves and rank abundance curves of $\alpha$-diversity. a) rarefaction curves plot, $\mathrm{X}$-axis is number sequencing reads randomly chosen from a certain sample to obtain OTUs. b) Rank-abundance curves of soil bacteria. CK, control group; SG, switchgrass group; AS, yarrow group; CG, Sheepgrass group; SS Kumadou group; SA, Kudouzi group; -r means rhizosphere soil samples.

the majority of microbe species (Fig. 5a). The rank abundance curve for OTUs showed that the bacterial richness of halophytes treated groups was higher than that of CK (Fig. 5b). It was evident for the differences in the bacterial richness (i.e., the Chao 1 value) listed in Table 3 .

\section{Bacterial Community Structure of Bacteria}

The taxonomic distributions of microbial communities were evaluated at different levels of classification. At the phylum level, the relative abundance of Proteobacteria and Acidobacteria phylum was increased by the halophyte planting treatment. However, the relative abundance of Bacteroidetes, Gemmatimonadetes, and Actinobacteria phylum were negatively regulated by the planting treatment (Fig. 6a). Seven dominant bacteria were identified, of which the relative abundance was shown in Fig. 6b). After halophyte planting, the abundance of Proteobacteria increased dramatically, followed by Acidobacteria. Interestingly, the relative abundance of all the increased bacteria in rhizosphere soil was higher than that in bulk soil; and the relative abundance of all the decreased bacteria in rhizosphere soil was lower than that in bulk soil (Fig. 6b). At the genus level, the dominant bacteria were Gemmatimonadaceae

Table 3 . The alpha diversity indexes in different groups.

\begin{tabular}{|c|c|c|c|c|c|}
\hline & Ace & Chao 1 & Shannon & Simpson & Goods_coverage \\
\hline $\mathrm{CK}$ & $634.77 \pm 42.14^{\mathrm{b}}$ & $677.99 \pm 48.87^{\mathrm{b}}$ & $6.696 \pm 0.32^{b}$ & $0.975 \pm 0.0055^{\mathrm{b}}$ & $0.995 \pm 0.0000^{\mathrm{b}}$ \\
\hline SG_r & $1631.46 \pm 21.85^{\mathrm{a}}$ & $1638.54 \pm 25.17^{\mathrm{a}}$ & $8.697 \pm 0.24^{\mathrm{a}}$ & $0.994 \pm 0.0015^{\mathrm{a}}$ & $0.988 \pm 0.0006^{\mathrm{a}}$ \\
\hline AS_r & $1589.38 \pm 52.14^{\mathrm{a}}$ & $1601.24 \pm 35.25^{\mathrm{a}}$ & $8.674 \pm 0.11^{\mathrm{a}}$ & $0.994 \pm 0.0006^{\mathrm{a}}$ & $0.988 \pm 0.0000^{\mathrm{a}}$ \\
\hline CG_r & $1434.60 \pm 109.48^{\mathrm{a}}$ & $1447.62 \pm 105.97^{\mathrm{a}}$ & $8.458 \pm 0.36^{\mathrm{a}}$ & $0.991 \pm 0.0040^{\mathrm{a}}$ & $0.990 \pm 0.0006^{\mathrm{a}}$ \\
\hline SS_r & $1502.15 \pm 90.43^{\mathrm{a}}$ & $1523.29 \pm 102.52^{\mathrm{a}}$ & $8.712 \pm 0.28^{\mathrm{a}}$ & $0.994 \pm 0.0012^{\mathrm{a}}$ & $0.990 \pm 0.0006^{\mathrm{a}}$ \\
\hline SA_r & $1536.32 \pm 57.68^{\mathrm{a}}$ & $1553.23 \pm 72.02^{\mathrm{a}}$ & $8.651 \pm 0.21^{\mathrm{a}}$ & $0.993 \pm 0.0015^{\mathrm{a}}$ & $0.989 \pm 0.0010^{\mathrm{a}}$ \\
\hline SG & $1630.62 \pm 103.25^{\mathrm{a}}$ & $1655.94 \pm 106.32^{\mathrm{a}}$ & $8.717 \pm 0.19^{\mathrm{a}}$ & $0.994 \pm 0.0015^{\mathrm{a}}$ & $0.988 \pm 0.0010^{\mathrm{a}}$ \\
\hline AS & $1535.50 \pm 49.75^{\mathrm{a}}$ & $1573.79 \pm 45.12^{\mathrm{a}}$ & $8.685 \pm 0.28^{a}$ & $0.994 \pm 0.0015^{\mathrm{a}}$ & $0.989 \pm 0.0010^{\mathrm{a}}$ \\
\hline CG & $1436.83 \pm 197.11^{a}$ & $1459.82 \pm 208.07^{\mathrm{a}}$ & $8.471 \pm 0.31^{\mathrm{a}}$ & $0.990 \pm 0.0036^{\mathrm{a}}$ & $0.990 \pm 0.0017^{\mathrm{a}}$ \\
\hline SS & $1606.31 \pm 80.76^{\mathrm{a}}$ & $1641.30 \pm 103.50^{a}$ & $8.966 \pm 0.03^{\mathrm{a}}$ & $0.995 \pm 0.0010^{\mathrm{a}}$ & $0.989 \pm 0.0015^{\mathrm{a}}$ \\
\hline SA & $1603.89 \pm 45.64^{\mathrm{a}}$ & $1628.28 \pm 70.38^{\mathrm{a}}$ & $8.857 \pm 0.15^{\mathrm{a}}$ & $0.995 \pm 0.0012^{\mathrm{a}}$ & $0.989 \pm 0.0006^{\mathrm{a}}$ \\
\hline
\end{tabular}

Data with different letters are significantly different $(\mathrm{p}<0.05)$. 
a) $)_{1.00}$

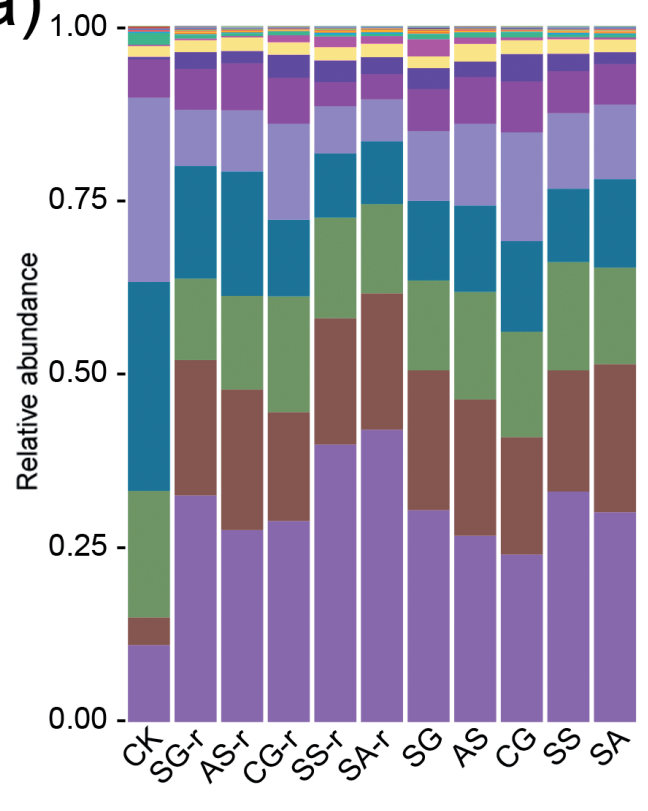

C)

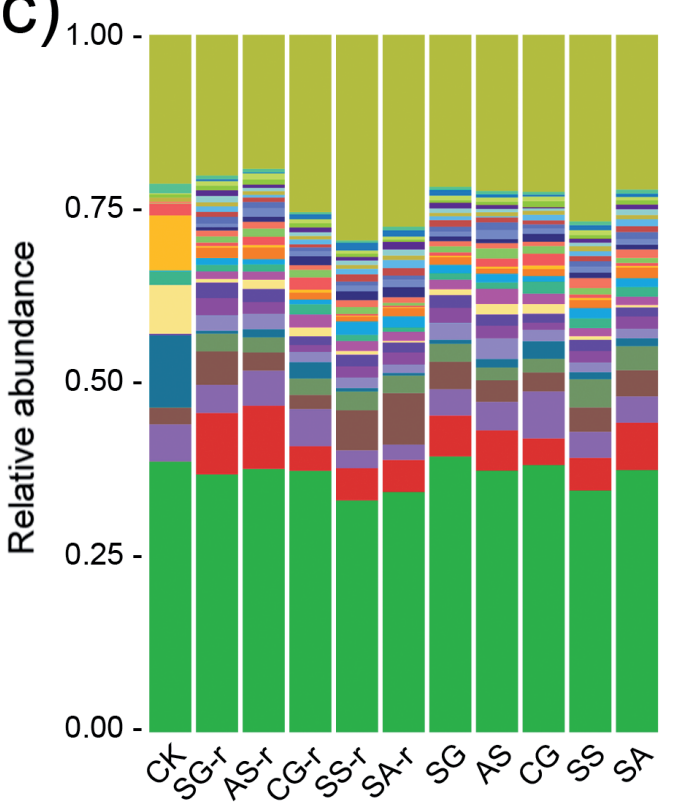

Genus

Phylum

Thaumarchaeota

Hydrogenedentes

WPS-2

BRC1

Chlamydiae

Rokubacteria
Elusimicrobia

Deinococcus-Thermus

Euryarchaeota

WS2

Entotheonellaeota

Fibrobacteres

Planctomycetes

Armatimonadetes

Unclassified

Nitrospirae

Firmicutes

Cyanobacteria

Verrucomicrobia

Patescibacteria

Actinobacteria

Gemmatimonadetes

Bacteroidetes

Acidobacteria

Proteobacteria

Others

f_Ambiguous_taxa_Unclassified Dongia

f_uncultured_soil_bacterium_Unclassified Gemmatimonas

Geobacter

Ramlibacter

f_Pedosphaeraceae_Unclassified

Pseudomonas

Lysobacte

UTCFX1

f__Saprospiraceae Unclassified

f_Blastocatellaceae_Unclassified

metagenome

Pontibacter

f AKYG1722 Unclassified

_-

MND1

Steroidobacter

f_uncultured_Unclassified

Ohtaekwangia

f_Longimicrobiaceae_Unclassified

Haliangium

Ellin6067

Flavisolibacter

f_Rhodothermaceae_Unclassified

f_Microscillaceae_Unclassified

Sphingomonas

f__uncultured bacterium Unclassified

f_Gemmatimonadaceae Unclassified

Unclassified

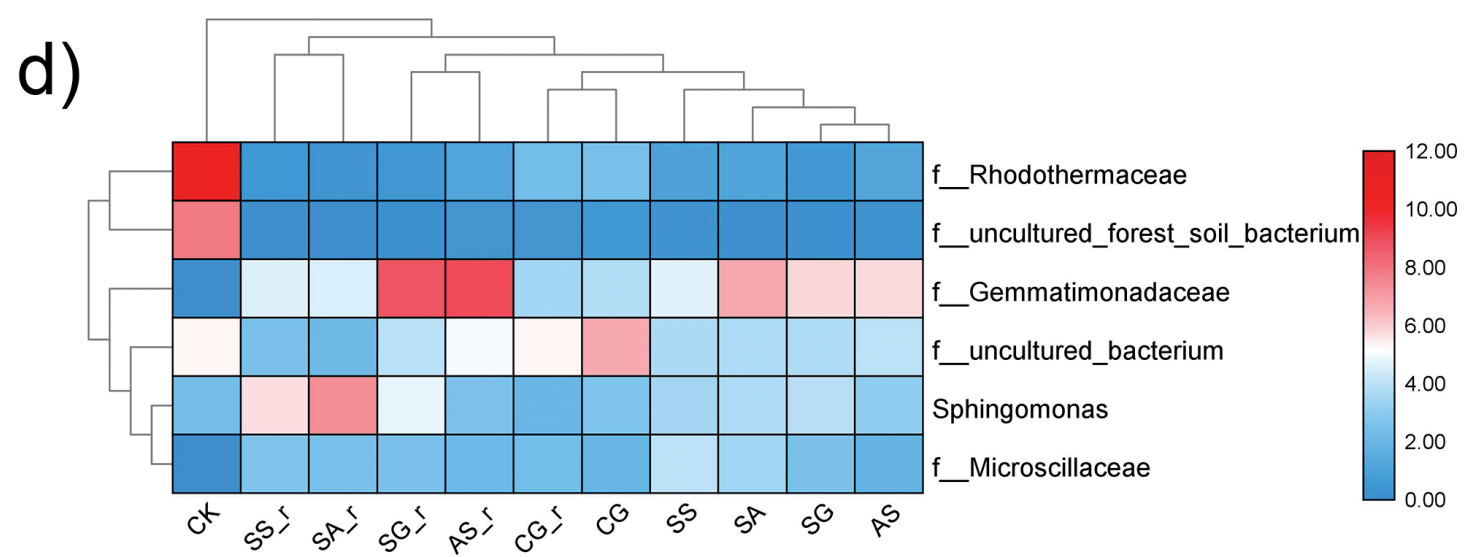

Fig. 6. Bacterial community structure. a, the relative abundance of bacteria at the phylum level; $b$, relative abundance of dominant bacteria at the phylum level; c, a, the relative abundance of bacteria at the genus level; d, relative abundance of dominant bacteria at the genus level. The larger the circle, the darker the color, the higher the proportion. CK, control group; SG, switchgrass group; AS, yarrow group; CG, Sheepgrass group; SS Kumadou group; SA, Kudouzi group; -r means rhizosphere soil samples. 
a)

$\square \mathrm{CK} \square \mathrm{SG} \square \mathrm{AS} \square \mathrm{CG} \square \mathrm{SS} \square \mathrm{SA}$

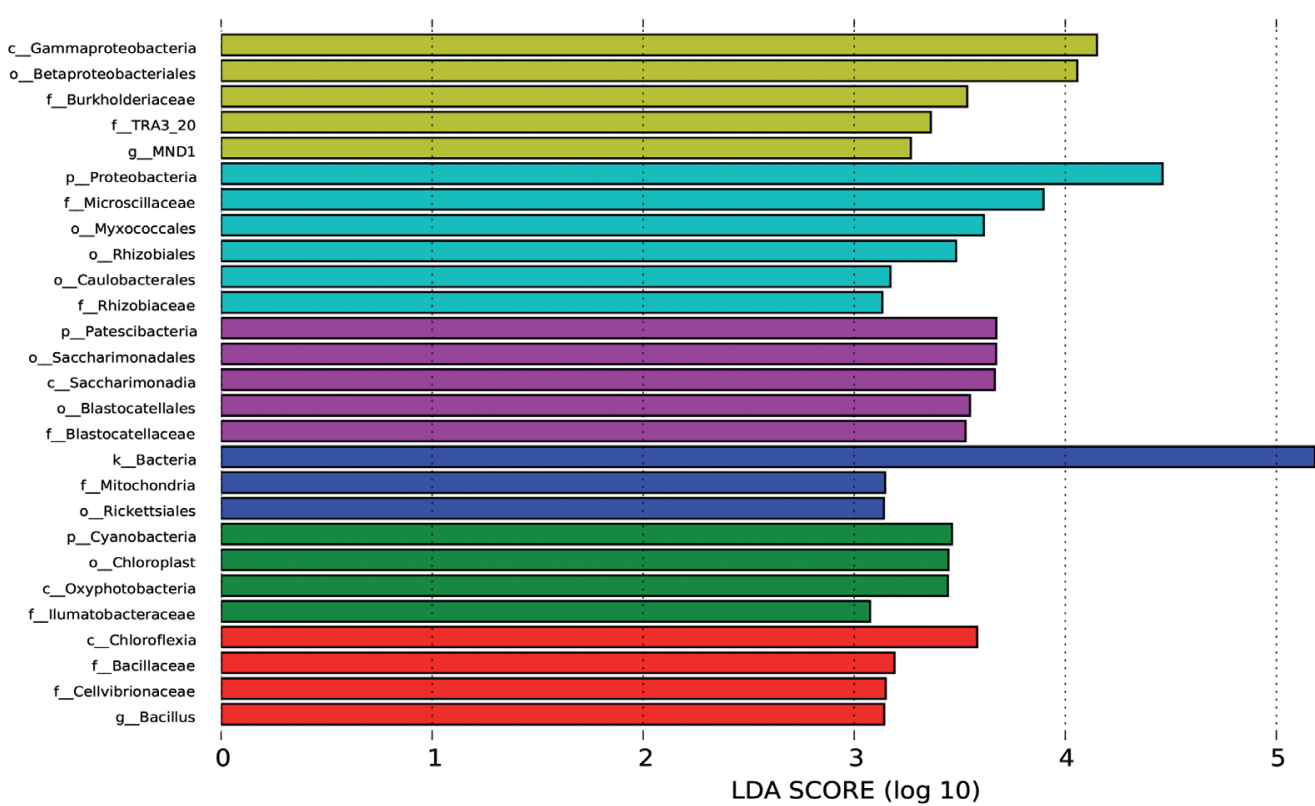

b)

\section{Cladogram}
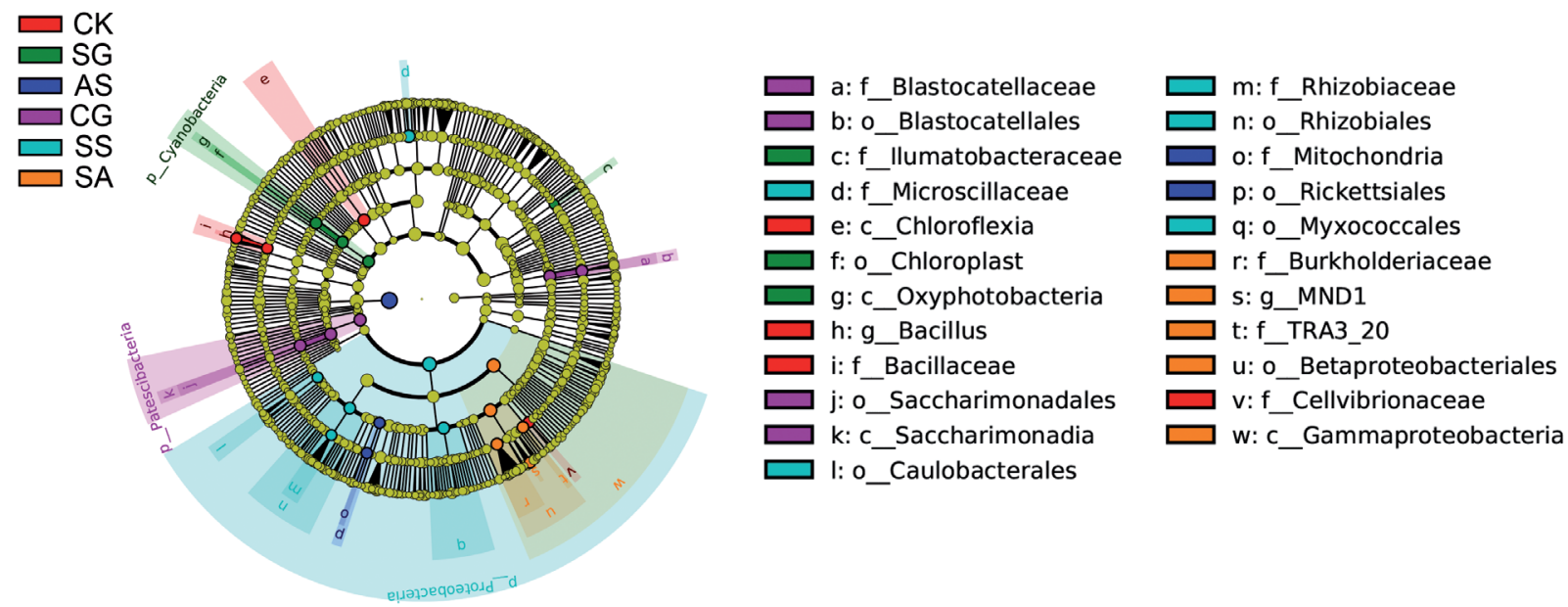

Fig. 7. Dominant bacteria in different classification level. The colored circles imply the dominant bacteria in relative abundance in different classification level. The larger the radius of the circles is, the higher the species in abundance. P: Phylum; C: Class; O: Order; F: Family; G: Genera.

(families), Rhodothermaceae (families), forest_soil_ bacterium (families), Sphingomonas (families), and Microscillaceae (families) (Fig. 6c). The relative abundance of Rhodothermaceae (families) and forest_ soil_bacterium (families) was decreased by the planting treatment, while Gemmatimonadaceae (families), Sphingomonas (families), and Microscillaceae (families) were increased (Fig. 6d).

\section{Results of Linear Discriminant Analysis}

The specific species that had a significant difference between groups was calculated using T-test and LEfSe (LDA Effect Size) analysis. At the phylum level, the relative abundance of Bacillus, Ellin6067, Haliangium,
MND1, Flavisolibacter, and Steroidobacter showed a remarkable difference $(p<0.001)$ in the CK group (Fig. $\mathrm{S} 1)$. As for the bacteria with a remarkable difference between rhizosphere soil group and bulk soil, there were Ellin6067, Haliangium, MND1, Steroidobacter, etc. (Fig. S1). Using GraPhlAnl, the dominant members at different classification levels are displayed as the classification tree (Figs 7a and b). A total of 23 taxa that had a discrepancy in relative abundance were presented in $\mathrm{CK}$ and halophyte planting treated groups (e.g., Gammaproteobacteria, Proteobacteria, Chloroflexia, etc.). The cladogram in Fig. 7b) showed the core bacterial species with a significant difference in $\mathrm{CK}$ and halophyte planting treated groups. 


\section{Discussion}

In this study, halophyte planting significantly reduced the soil $\mathrm{pH}$ value, total salt content, and ESP of the saline-alkali soil, which was similar to previous studies [21-24]. These studies, including ours, showed that planting halophytes had positive effects on the remediation of saline-alkali soil. In particular, the TN, $\mathrm{OM}$, and AP in saline-alkali soil have significantly been improved after planting. The physical properties of saline-alkali soil are improved due to the interspersed roots of salt-tolerant plants [1]. After the cultivation of halophytes, we believe that Sphaerophysa salsula (Pall.) DC. had the greatest impact on soil physical properties, while Achnatherum splendens had the smallest. In addition, AWC, total porosity, and capillary porosity were also increased after halophyte planting. Su et al. reported that higher soil moisture and OM contents favoring biodegradation in soil and improving microbial activity and soil adsorption $[25,26]$. Previous studies have shown that if the vegetation litter is reduced, soil OM cannot be replenished [27]. At the same time, wind erosion and freeze-thaw action continuously accelerate the mineralization of soil OM, which will greatly reduce soil fertility [28, 29]. The planting of halophytes had greatly supplemented the OM, which led to the improvement of fertility and salinity. Among all the planted halophytes, we were impressed by the improvement of Sphaerophysa salsula (Pall.) DC. on the saline-alkali soil. Sphaerophysa salsula (Pall.) DC. is a species of flowering plant in the legume family known by the common name alkali swainsonpea [30]. It is native to Asia, but it is known in many other parts of the world as an introduced species. It grows in cultivated land and disturbed habitat, easily tolerating alkaline substrates [30]. In addition, Sphaerophysa salsula (Pall.) DC. is rich in protein and oil. Compared with other halophytes, Sphaerophysa salsula (Pall.) $D C$. has more biomass and strong salt tolerance, which may be the main reason for its ability to improve salinealkali soil.

Bacteria play important roles in the conversion of soil organic and inorganic matter. Bacteria diversity can be affected by many factors, including soil conditions, seasonal plants, and age [31]. The results of alpha diversity showed that the soil microbial species, abundance, and evenness had been greatly improved after halophyte planting, which was consistent with previous studies $[32,33]$. We found that Proteobacteria was the most dominant bacteria after halophyte planting. Members of the phylum Proteobacteria can degrade a wide range of macromolecules [34], which are reported to compose the critical phyla in OM degradation [35]. The relative abundance of Proteobacteria in Rhizosphere was higher than that in bulk soil, which indicated that root exudates might promote Proteobacteria growth, especially in Sphaerophysa salsula (Pall.) DC. and Sophora alopecuroides L.. This interaction might be one of the reasons why Sphaerophysa salsula (Pall.)
DC. and Sophora alopecuroides L. showed a better improvement on the saline-alkali soil. It is known that Proteobacteria dominates in the reactors treating high-nitrate wastewater, and many types of denitrifies are included in the phylum Proteobacteria. In this study, the value of $\mathrm{TN}$ and $\mathrm{HyN}$ was significantly increased by Sphaerophysa salsula (Pall.) DC. and Sophora alopecuroides L. planting. Moreover, the abundance of Proteobacteria is higher in these two groups than that in other groups. Beyond all doubt, the increase in $\mathrm{TN}$ and HyN was mainly due to the accumulation of Proteobacteria members. Actinobacteria, of which most members grow at a $\mathrm{pH}$ value of 5.79-5.82, is an essential indicator for soil $\mathrm{pH}$ [36]. In the soil with vegetation, Acidobacteria usually had a higher relative abundance [37]. In the present results, the soil $\mathrm{pH}$ was decreased, which lead to an increase of Acidobacteria. Moreover, the relative abundance of Bacteroidetes, Gemmatimonadetes, and Actinobacteria phylum were negatively regulated by the planting treatment. Lauber found a positive correlation between the $\mathrm{pH}$ value and the relative abundance of Bacteroidetes [38]. Also, Ganzert et al. noted that Bacteroidetes preferred higher values of soil $\mathrm{pH}$ and emphasized that $\mathrm{pH}$ is the main factor for shaping bacterial community [39]. Hence, we believed that the decrease in Bacteroidetes abundance was mainly due to the changes in $\mathrm{pH}$. The previous study had shown that some taxa of Gemmatimonadetes are beneficial for maintaining or improving soil fertility [40]. In addition, researchers found that Gemmatimonadetes was a new phototrophic bacterial phylum, which played a crucial role in the oxidation of organic compounds and fixation of $\mathrm{N}_{2}$ [41, 42]. The competition of other bacteria might cause a decrease in Gemmatimonadetes. Soil enzyme activity is one of the critical factors during nutrient cycling in soils [43-45], which were closely related to soil microorganisms and soil OM. In our results, we found that the halophyte planting treatment significantly increased the soil enzyme activities. This might be caused by the plant themself and their interactions with microorganisms. The sharp increase in enzyme activity also proved the practicality of halophyte planting practice for saline-alkali soil improvement.

\section{Conclusions}

Halophyte planting has significant impact on the restoration of saline-alkali soil. It increases the content of organic matter, total nitrogen, total phosphorus, available phosphorus, and alkali-hydrolyzed nitrogen in the soil. Meanwhile, the soil after cultivation has more water content and higher porosity, which provides a good foundation for the survival of microorganisms. The results of soil physical and chemical properties show that Sphaerophysa salsula (Pall.) DC. (Sphaerophysa salsula) has the most significant improvement effect 
on saline-alkali land. Soil bacteria 16S RNA amplicon sequencing results showed that Proteobacteria plays a crucial role in the degradation of soil organic matter, which may be an important factor in improving salinealkali soil. Besides, root exudates of halophytes might promote Proteobacteria growth, especially in Sphaerophysa salsula (Pall.) DC. and Sophora alopecuroides L. (Sophora alopecuroides). In addition, the abundance changes of several bacteria (e.g., Actinobacteria, Bacteroidetes) due to the decrease in $\mathrm{pH}$. These results can provide reference methods for the biological improvement of saline-alkali soils. Also, it provides a theoretical basis for the establishment of other biological improvement methods for saline-alkali soils.

\section{Funding}

This research was funded by National Key Research and Development Project (2016YFC0501307), Key Research and Development plan of Ningxia Hui Autonomous Region 2019BBF02001 and 2018BBF23008. The funders had no role in study design, data collection and analysis, decision to publish, or preparation of the manuscript.

\section{Data Availability Statement}

Our data has been uploaded, and the database address and login number are https://bigd.big.ac.cn/ CRA003680.

\section{Author Contributions}

Xueqin Wang summarized the sequencing data, performed the data analysis and prepared the original manuscript.

Fengju Zhang and Bo Zhang attended discussion and revised manuscript.

$\mathrm{Xing} \mathrm{Xu}$ designed the experiment and revised the manuscript.

All authors approved the final manuscript.

\section{Conflicts of Interest}

The authors declare no conflict of interest

\section{References}

1. XUEQIN WANG X.X., FENGJU ZHANG, KONG XIN Biological improvement of saline alkali soil reference system: A review. Sciences in Cold and Arid Regions, 10 (6), 516, 2018.

2. MUNNS R. Comparative physiology of salt and water stress. Plant Cell Environ., 25 (2), 239, 2002.

3. ZAKERY-ASL M.A., BOLANDNAZAR S., OUSTAN S. Effect of salinity and nitrogen on growth, sodium, potassium accumulation, and osmotic adjustment of halophyte Suaeda aegyptiaca (Hasselq.) Zoh. Arch. Agron. Soil Sci., 60 (6), 785, 2014.
4. JIA T., WANG J., CHANG W., FAN X., SUI X., SONG F. Proteomics Analysis of E. angustifolia Seedlings Inoculated with Arbuscular Mycorrhizal Fungi under Salt Stress. Int. J. Mol. Sci., 20 (3), 788, 2019.

5. PANTA S., FLOWERS T., LANE P., DOYLE R., HAROS G., SHABALA S. Halophyte agriculture: Success stories. Environ. Exp. Bot., 107, 71, 2014.

6. ROZEMA J., MUSCOLO A., FLOWERS T. Special Issue: Sustainable cultivation and exploitation of halophyte crops in a salinizing world. Environ. Exp. Bot., 92, 1, 2013.

7. LONG R., LI M., ZHANG T., KANG J., SUN Y., CONG L., GAO Y., LIU F., YANG Q. Comparative Proteomic Analysis Reveals Differential Root Proteins in Medicago sativa and Medicago truncatula in Response to Salt Stress. Front. Plant Sci., 7, 424, 2016.

8. ADESEMOYE A.O., OBINI M., UGOJI E.O. Comparison of plant growth-promotion with Pseudomonas aeruginosa and Bacillus subtilis in three vegetables. Braz. J. Microbiol., 39 (3), 423, 2008.

9. BHATTI G.A., QURESHI P.N., QURESHI A., SULTANA $\mathrm{K}$. Studies on heat shock response of wheat seedlings using E. coli GroEL antibodies. Pakphyton, 5, 157, 2020.

10. AFRASAYAB S., FAISAL M., HASNAIN S. Comparative study of wild and transformed salt tolerant bacterial strains on Triticum aestivum growth under salt stress. Braz. J. Microbiol., 41 (4), 946, 2010.

11. LIU W.-G., LIU J.-X., YAO M.-L., MA Q.-F. Salt tolerance of a wild ecotype of vetiver grass (Vetiveria zizanioides L.) in southern China. Bot. Stud., 57 (1), 27, 2016.

12. PARIDA A.K., DAS A.B. Salt tolerance and salinity effects on plants: a review. Ecotox. Environ. Safe., 60 (3), 324, 2005.

13. LING N., RAZA W., MA J., HUANG Q., SHEN Q. Identification and role of organic acids in watermelon root exudates for recruiting Paenibacillus polymyxa SQR-21 in the rhizosphere. Eur. J. Soil Biol., 47 (6), 374, 2011.

14. BADRI D.V., VIVANCO J.M. Regulation and function of root exudates. Plant Cell Environ., 32 (6), 666, 2009.

15. IGIEHON N.O., BABALOLA O.O. Rhizosphere Microbiome Modulators: Contributions of Nitrogen Fixing Bacteria towards Sustainable Agriculture. Int. J. Env. Res. Pub. He., 15 (4), 574, 2018.

16. ZHANG J., YANG G., JI C. The relationship between the vertical distribution of soil arthropod and soil factors in saline-alkali Lycium barbarum plantation. J. Agr. Sci., 37 (3), 11, 2016.

17. LU R., Soil and Agricultural Chemistry Analysis Methods, Beijing: China Agricultural Science and Technology Press, 2002 [In Chinese].

18. TSUDA A., SUDA W., MORITA H., TAKANASHI K., TAKAGI A., KOGA Y., HATTORI M. Influence of Proton-Pump Inhibitors on the Luminal Microbiota in the Gastrointestinal Tract. Clin. Transl. Gastroen., 6 (6), e89, 2015.

19. LU Z., DENG Y., VAN NOSTRAND J.D., HE Z., VOORDECKERS J., ZHOU A., LEE Y.J., MASON O. U., DUBINSKY E.A., CHAVARRIA K.L., TOM L.M., FORTNEY J.L., LAMENDELLA R., JANSSON J.K., D'HAESELEER P., HAZEN T.C., ZHOU J. Microbial gene functions enriched in the Deepwater Horizon deepsea oil plume. ISME J., 6 (2), 451, 2012.

20. YANG Y., WU L., LIN Q., YUAN M., XU D., YU H., HU Y., DUAN J., LI X., HE Z., XUE K., VAN NOSTRAND J., WANG S., ZHOU J. Responses of the functional structure of soil microbial community to livestock grazing in the 
Tibetan alpine grassland. Glob Chang Biol., 19 (2), 637, 2013.

21. XU Z., SHAO T., LV Z., YUE Y., LIU A., LONG X., ZHOU Z., GAO X., RENGEL Z. The mechanisms of improving coastal saline soils by planting rice. Sci. Total Environ., 703, 135529, 2020.

22. ZHANG T., ZHAN X., KANG Y., WAN S., FENG H. Improvements of soil salt characteristics and nutrient status in an impermeable saline-sodic soil reclaimed with an improved drip irrigation while ridge planting Lycium barbarum L. J. Soil. Sediment., 17 (4), 1126, 2017.

23. LU S., WANG C., DU Y., WU Y., GAO Y., LIU S. Effects of rice planting years on physicochemical property and fungi community in soda saline-alkali soil. Journal of South China Agricultural University, 40 (1), 15, 2019.

24. XIA J., REN J., ZHANG S., WANG Y., FANG Y. Forest and grass composite patterns improve the soil quality in the coastal saline-alkali land of the Yellow River Delta, China. Geoderma, 349, 25, 2019.

25. SU W., HAO H., DING M., WU R., XU H., XUE F., SHEN C., SUN L., LU C. Adsorption and degradation of imazapic in soils under different environmental conditions. PloS one, 14 (7), e0219462-e0219462, 2019.

26. KRAUSS M., WILCKE W. Sorption Strength of Persistent Organic Pollutants in Particle-size Fractions of Urban Soils. Soil Sci. Soc. Am. J., 66 (2), 430, 2002.

27. WU C., LI Y., CHEN M., LUO X., CHEN Y., BELZILE N., HUANG S. Adsorption of Cadmium on Degraded Soils Amended with Maize-Stalk-Derived Biochar. Int. J. Env. Res. Pub. He., 15 (11), 2331, 2018

28. SIX J., BOSSUYT H., DEGRYZE S., DENEF K. A history of research on the link between (micro)aggregates, soil biota, and soil organic matter dynamics. Soil Till. Res., 79 (1), 7, 2004.

29. WAN T., TU W., XI H., LI Y., TANG X., YANG Y. Study on Vegetation and Soil Characteristics of Desertification Grassland in Northwest Sichuan. Acta Agrestia Sinica, 13, 650, 2013.

30. LI G., ZHAO P., SHAO W., Cash Crop Halophytes of China, in Sabkha Ecosystems: Volume VI: Asia/Pacific, B. Gul, et al., Editors. 2019, Springer International Publishing: Cham. p. 497-504.

31. HRYNKIEWICZ K., BAUM C., LEINWEBER P. Density, metabolic activity, and identity of cultivable rhizosphere bacteria on Salix viminalis in disturbed arable and landfill soils. J. Plant Nutr. Soil Sci., 173 (5), 747, 2010

32. WANG F., LIANG Y., JIANG Y., YANG Y., XUE K., XIONG J., ZHOU J., SUN B. Planting increases the abundance and structure complexity of soil core functional genes relevant to carbon and nitrogen cycling. Sci. RepUK, 5 (1), 14345, 2015.

33. XIAO C., YANG L., ZHANG L., LIU C., HAN M. Effects of cultivation ages and modes on microbial diversity in the rhizosphere soil of Panax ginseng. J. Ginseng Res., 40 (1), 28, 2016.
34. CHOUARI R., LE PASLIER D., DAEGELEN P., GINESTET P., WEISSENBACH J., SGHIR A. Novel predominant archaeal and bacterial groups revealed by molecular analysis of an anaerobic sludge digester. Environ. Microbiol., 7 (8), 1104, 2005.

35. RIVIÈRE D., DESVIGNES V., PELLETIER E., CHAUSSONNERIE S., GUERMAZI S., WEISSENBACH J., LI T., CAMACHO P., SGHIR A. Towards the definition of a core of microorganisms involved in anaerobic digestion of sludge. ISME J., 3 (6), 700, 2009.

36. CHAUDHARY D.K., KHULAN A., KIM J. Development of a novel cultivation technique for uncultured soil bacteria. Sci. Rep-UK, 9 (1), 6666, 2019.

37. LIN Y.-T., HU H.-W., WHITMAN W. B., COLEMAN D.C., CHIU C.-Y. Comparison of soil bacterial communities in a natural hardwood forest and coniferous plantations in perhumid subtropical low mountains. Bot. Stud., 55 (1), 50, 2014.

38. LAUBER C.L., HAMADY M., KNIGHT R., FIERER N. Pyrosequencing-Based Assessment of Soil $\mathrm{pH}$ as a Predictor of Soil Bacterial Community Structure at the Continental Scale. Appl. Environ. Microb., 75 (15), 5111, 2009.

39. GANZERT L., BAJERSKI F., WAGNER D. Bacterial community composition and diversity of five different permafrost-affected soils of Northeast Greenland. FEMS Microbiol. Ecol., 89 (2), 426, 2014.

40. ZHANG Z., ZHANG P., LIN Q., CHA Z., LUO W. Response of bacterial communities in rubber plantations to different fertilizer treatments. 3 Biotech, 9 (8), 293, 2019.

41. ZENG Y., FENG F., MEDOVá H., DEAN J., KOBLíŽEK M. Functional type 2 photosynthetic reaction centers found in the rare bacterial phylum Gemmatimonadetes. P. Natl. A. Sci., 111 (21), 7795, 2014.

42. DUBBS J. M., ROBERT TABITA F. Regulators of nonsulfur purple phototrophic bacteria and the interactive control of $\mathrm{CO}_{2}$ assimilation, nitrogen fixation, hydrogen metabolism and energy generation. FEMS Microbiol. Rev., 28 (3), 353, 2004.

43. CAI Z., WANG J., MA J., ZHU X., CAI J., YANG G. Anaerobic Degradation Pathway of the Novel Chiral Insecticide Paichongding and Its Impact on Bacterial Communities in Soils. J Agr. Food Chem., 63 (32), 7151, 2015.

44. ASAD M.A.U., LAVOIE M., SONG H., JIN Y., FU Z., QIAN H. Interaction of chiral herbicides with soil microorganisms, algae and vascular plants. Sci. Total Environ., 580, 1287, 2017.

45. CAI Z., RONG Y., CHEN J., WANG J., MA J., ZHANG W., ZHAO X. Effects of the novel cis-nitromethylene neonicotinoid insecticide Paichongding on enzyme activities and microorganisms in yellow loam and Huangshi soils. Environ. Sci. Pollut. R., 23 (8), 7786, 2016. 


\section{Supplementary Material}

Table S1. Sequence data summary.

\begin{tabular}{|c|c|c|c|c|c|c|c|c|c|c|}
\hline Sample & Length(bp) & \#Reads & $\operatorname{Bases}(b p)$ & Q20(\%) & Q30(\%) & $\mathrm{GC}(\%)$ & \#PE_reads & \#Nochimera & AvgLen(bp) & $\mathrm{GC}(\%)$ \\
\hline CK_1 & 250 & 111934 & 27983500 & 86,81 & 80,5 & 58,55 & 55967 & 42884 & 454,57 & 58,23 \\
\hline CK_2 & 250 & 109290 & 27322500 & 93,02 & 89,01 & 58,71 & 54645 & 48270 & 454,42 & 58,7 \\
\hline CK_3 & 250 & 92426 & 23106500 & 93,12 & 89,24 & 57,85 & 46213 & 40817 & 453,48 & 57,86 \\
\hline SG_r_1 & 250 & 108074 & 27018500 & 92,45 & 88,49 & 56,13 & 54037 & 47457 & 455,79 & 56,01 \\
\hline SG_r_2 & 250 & 101772 & 25443000 & 92,35 & 88,35 & 56,33 & 50886 & 44672 & 456,38 & 56,21 \\
\hline SG_r_3 & 250 & 95816 & 23954000 & 92,5 & 88,62 & 55,91 & 47908 & 41797 & 454,73 & 55,8 \\
\hline AS_r_1 & 250 & 144822 & 36205500 & 90,97 & 86,36 & 56,92 & 72411 & 61945 & 454,95 & 56,77 \\
\hline AS_r_2 & 250 & 129576 & 32394000 & 92,18 & 88,1 & 56,51 & 64788 & 56345 & 454,75 & 56,43 \\
\hline AS_r_3 & 250 & 108660 & 27165000 & 92,36 & 88,35 & 56,09 & 54330 & 47632 & 456,54 & 55,95 \\
\hline CG_r_1 & 250 & 99866 & 24966500 & 91,98 & 87,84 & 56,3 & 49933 & 42952 & 452,49 & 56,18 \\
\hline CG_r_2 & 250 & 161552 & 40388000 & 92,48 & 88,59 & 55,77 & 80776 & 71014 & 455,03 & 55,66 \\
\hline CG_r_3 & 250 & 105318 & 26329500 & 87,69 & 82,03 & 56,26 & 52659 & 41312 & 452,68 & 56,03 \\
\hline SS_r_1 & 250 & 101630 & 25407500 & 88,37 & 83,2 & 54,84 & 50815 & 40551 & 451,51 & 54,65 \\
\hline SS_r_2 & 250 & 98192 & 24548000 & 88,3 & 82,98 & 55,5 & 49096 & 39340 & 454,96 & 55,24 \\
\hline SS_r_3 & 250 & 87466 & 21866500 & 85,68 & 79,52 & 55,89 & 43733 & 32043 & 454,62 & 55,55 \\
\hline SA_r_1 & 250 & 101460 & 25365000 & 88 & 82,58 & 55,68 & 50730 & 40540 & 455,17 & 55,39 \\
\hline SA_r_2 & 250 & 93802 & 23450500 & 88,17 & 82,89 & 55,06 & 46901 & 37675 & 452,58 & 54,88 \\
\hline SA_r_3 & 250 & 124930 & 31232500 & 87,39 & 81,78 & 55,53 & 62465 & 48827 & 454,47 & 55,22 \\
\hline SG_1 & 250 & 105962 & 26490500 & 93,58 & 90,1 & 55,87 & 52981 & 46888 & 453,74 & 55,82 \\
\hline SG_2 & 250 & 90334 & 22583500 & 92,78 & 89,02 & 55,65 & 45167 & 39545 & 454,32 & 55,56 \\
\hline SG_3 & 250 & 100158 & 25039500 & 93,57 & 90,06 & 56,13 & 50079 & 44544 & 455,07 & 56,05 \\
\hline AS_1 & 250 & 89306 & 22326500 & 93,67 & 90,2 & 56,03 & 44653 & 39610 & 453,92 & 56,01 \\
\hline AS_2 & 250 & 85168 & 21292000 & 93,29 & 89,69 & 56,03 & 42584 & 37495 & 454,4 & 55,99 \\
\hline AS_3 & 250 & 100870 & 25217500 & 93,62 & 90,15 & 55,94 & 50435 & 44971 & 454,6 & 55,86 \\
\hline CG_1 & 250 & 92324 & 23081000 & 92,46 & 88,48 & 56,24 & 46162 & 40187 & 452,01 & 56,18 \\
\hline CG_2 & 250 & 104168 & 26042000 & 92,55 & 88,64 & 56,02 & 52084 & 45868 & 455,5 & 55,88 \\
\hline CG_3 & 250 & 93616 & 23404000 & 92,43 & 88,42 & 56,53 & 46808 & 41130 & 452,45 & 56,5 \\
\hline SS_1 & 250 & 112828 & 28207000 & 91,17 & 86,73 & 56,03 & 56414 & 48037 & 453,03 & 55,92 \\
\hline SS_2 & 250 & 135620 & 33905000 & 92,62 & 88,77 & 55,64 & 67810 & 59665 & 455,33 & 55,52 \\
\hline SS_3 & 250 & 103198 & 25799500 & 92,74 & 88,88 & 55,6 & 51599 & 45795 & 453,79 & 55,5 \\
\hline SA_1 & 250 & 100618 & 25154500 & 92,37 & 88,37 & 55,73 & 50309 & 44402 & 455,65 & 55,58 \\
\hline SA_2 & 250 & 85164 & 21291000 & 90,85 & 86,14 & 56,84 & 42582 & 36519 & 453,59 & 56,55 \\
\hline SA_3 & 250 & 85046 & 21261500 & 91,65 & 87,31 & 56,12 & 42523 & 37086 & 454,57 & 55,78 \\
\hline
\end{tabular}

CK, control group; SG, switchgrass group; AS, yarrow group; CG, Sheepgrass group; SS Kumadou group; SA, Kudouzi group; -r means rhizosphere soil samples; _1, 2 and _ 3 means biological replicates. 


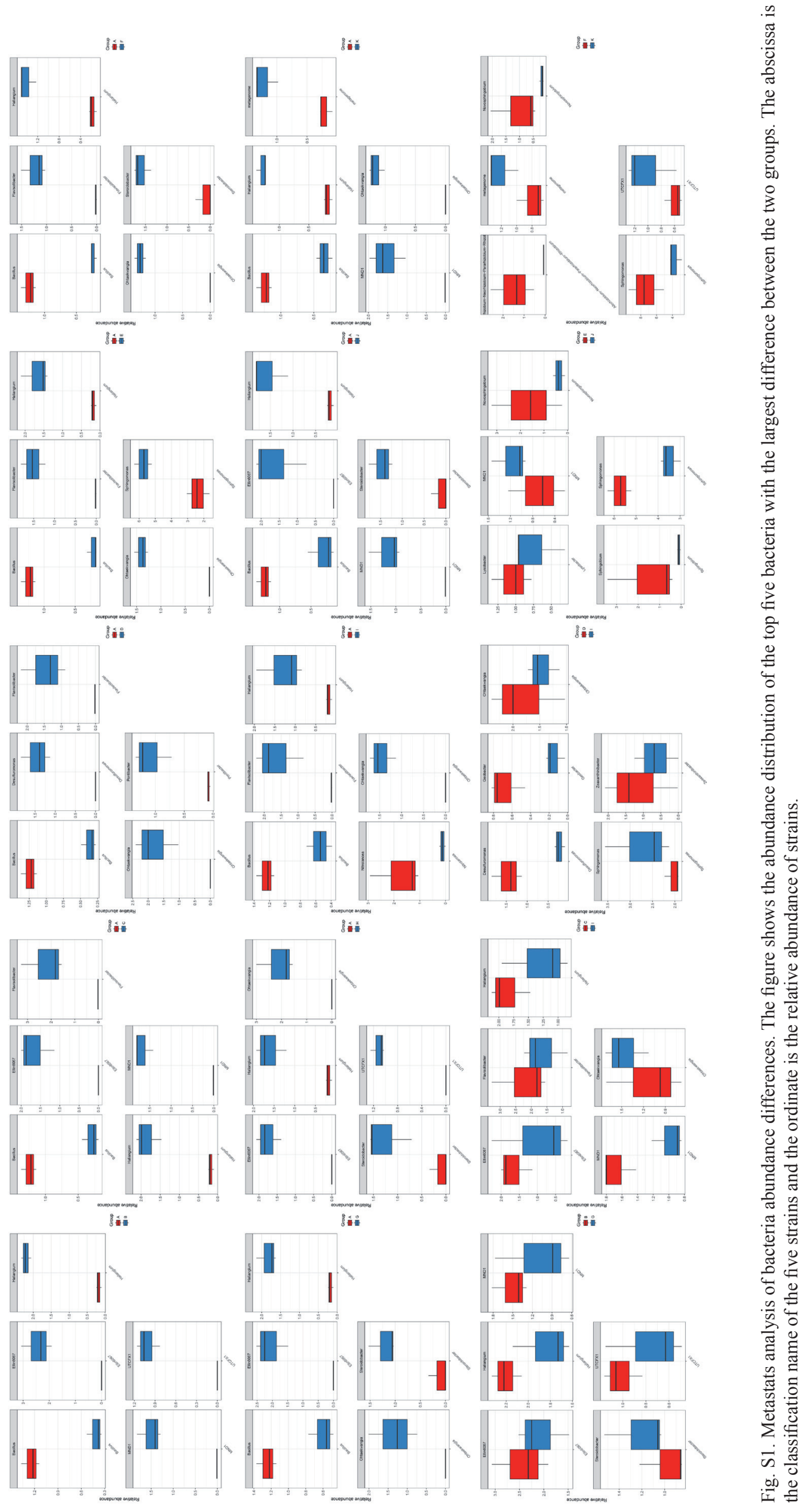


